\section{Effect of prophylactic}

Polishing protocols and

mouthrinses on the surface

roughness of different

Adhesive restorative materials

\section{Profilaktik polisaj protokolleri}

ve ağız gargaralarının farklı

adeziv restoratif materyallerin

yüzey pürüzlülüğü üzerine

\section{Etkisi}

\section{Assist. Prof. Tuğba Toz Akalın}

Istanbul Medipol University, Department of

Restorative Dentistry, Faculty of Dentistry, Istanbul

\section{Dr. Becen Demir}

Private Practice, Istanbul

Assist. Prof. Funda Öztürk Bozkurt Istanbul Medipol University, Department of Restorative Dentistry, Faculty of Dentistry, Istanbul

\section{Assist. Prof. Harika Gözükara Bag}

Inonu University, Department of Biostatistics, Faculty of Medicine, Malatya

\section{Assoc. Prof. Safa Tuncer}

Istanbul University, Department of Restorative Dentistry, Faculty of Dentistry, Istanbul

Received : 14 Jan 2016

Accepted: 30 March 2016

DOI: 10.5505/yeditepe.2016.35744

Corresponding author:

Assist. Prof. Funda Öztürk Bozkurt

Istanbul Medipol University, Department of

Restorative Dentistry, School of Dentistry, Istanbul

Ataturk Bulvarı 34083, Fatih, İstanbul

Mobile phone: +905323565505

Fax: +902125210426

E-posta: fbozkurt@medipol.edu.tr

\section{SUMMARY}

Aim: The aim of this study was to evaluate the effects of prophylactic polishing protocols and mouth rinses on surface roughness of different tooth colored restoratives that were generally preferred for Class $\mathrm{V}$ cavities.

Materials and Methods: A reinforced conventional glass ionomer, a resin modified glass ionomer, a flowable, and a nanohybrid composite were used. Forty specimens for each restorative materials were fabricated and polished and baseline surface roughness $(\mathrm{Ra})$ measurements were obtained by a profilometer. Then the specimens were divided into two groups according to prophylactic polishing pro-tocols: ultrasonic scaling or ultrasonic scaling and air polishing. Following Ra measurements prophy-lactic polishing protocols groups were divided into two subgroups for two different mouth rinses im-mersion and Ra measurements were obtained afterwards. Finally the specimens were re-polished and Ra values were recorded.

Results: Prophylactic polishing protocols, especially air polishing, resulted in significant increases in surface roughness $(p<0.001)$ while mouth rinses had minimal effects $(p>0.05)$. Re-polishing proce-dures decreased surface roughness values. Tested glass ionomers showed worse surface roughness values compared with resin composites.

Conclusion: Result of this research indicated that prophylactic polishing protocols increased surface roughness values of restorative materials, especially glass ionomers.

Key words: Resin composite, glass ionomer, prophylactic polishing protocols.

\section{ÖZET}

Amaç: Bu çalışmanın amacı profilaktik polisaj protokolleri ve ağız gargaralarının genellikle sınıf $\mathrm{V}$ kaviteler için tercih edilen farklı adeziv restoratif materyallerin yüzey pürüzlülüğü üzerine etkisini incelemektir.

Gereç ve Yöntem: Güçlendirilmiş geleneksel cam iyonomer, rezin modifiye cam iyonomer, akışkan composit ve nanohibrid kompozit kullanılmıştır. Her restoratif materyalden 40 örnek hazır- 
lanmış, polisaj yapıımış ve profilometre ile başlangıç yüzey pürüzlülüğü ölçümleri elde edilmiştir. Örnekler daha sonra profilaktik polisaj protokollerine göre iki gruba ayrımıştı: ultrasonic temizleme; ultrasonic temizleme ve air polishing. Ra değerlerinin elde edilmesinin ardından gruplar iki alt gru-ba ayrımış ve farkıı iki ağız gargasına maruz kalmış ve Ra değerleri elde edilmiştir. Son olarak örnekler tekrar polisajlanıp son Ra ölçümleri alınmıştır.

Bulgular: Profilaktik polisaj protokolları, özellikle air polishing, yüzey pürüzlülüğünde anlamlı derecede artışa sebep olurken $(p<0.001)$, ağız gargaraları etkisi az olmuştur ( $p>0.05$ ). Tekrar polisajlama uygulaması yüzey pürüzlülüğünü değerlerini düşürmüştür. Kompozitlerle karşılaştırılığında test edilen cam iyonomerler daha kötü yüzey pürüzlülüğü değerleri vermiştir.

Sonuç: Bu çalışmanın sonucu profilaktik polisaj protokollerinin restoratif materyallerin özellikle cam iyonomerlerin yüzey pürüzlülüğünü artırdığını göstermiştir.

Anahtar Kelimeler: Kompozit rezin, cam iyonomer, profilaktik polisaj protokolü

\section{INTRODUCTION}

Clinicians generally provide scaling and polishing for most of their patients at recall appointments even if the patients are in low risk group for periodontal disease. Scaling could be described as the removal of dental plaque, mineralized deposits like calculus, debris and/or external staining. Sharpened dental curettes or ultrasonic scalers can be used for these procedures. Polishing procedure is the removal of any extrinsic stain, with rubber cup or bristle brush loaded with a prophylaxis paste in low speed handpiece, and/or air polishing devices.' Air polishing which is more efficacious, convenient and needs less chair time compared to rubber cups or brushes, ${ }^{2,3}$ air and water pressure are mixed with an abrasive powder and remaining extrinsic stains are removed after scaling procedures. ${ }^{4}$

Besides daily oral hygiene procedures, professional tooth cleaning can be recommended once in a six months peri- od or more frequently for severe cases of periodontal disease. Antibacterial mouth rinses and dentifrices may also be to prescribed for controlling the biofilm. ${ }^{5}$ However their effect on preventing periodontitis has not been established, ${ }^{5}$ mechanical cleaning with dentifrices and mouthwashes can reduce gingivitis, ${ }^{6,7}$ Listerine Coolmint (Johnson \& Johnson Limited, Maidenhead, UK) is composed of a combination of essential oils such as thymol, eucalyptol, methyl salicylate, and men-thol and it includes $21.6 \%$ to $26.6 \%$ ethanol depending on the product. The alcohol in the mouth rins-es have an antiseptic effect and also enables the breaking down or dissolving of active principles. ${ }^{6} \mathrm{Re}-$ cently, an alcohol-free oral rinse product (Oral-B Pro-Expert Clinic Line, Procter \& Gamble, Gross Gerau, Germany) was introduced to the market for the elimination of plaque formation and develop-ment of gingivitis. It contains cetylpyridinium chloride (CPC) and this antimicrobial ingredient causes cell death by inhibition of cell growth, disruption of bacterial metabolism and leakage of cell components. ${ }^{8,9}$

The effects of scaling on tooth surfaces have been investigated, ${ }^{10,11}$ however there is limited information about their effects on esthetic restorative materials.12,13 In addition, the ingredients of mouth rinses may detoriate the composite resin surface. ${ }^{14}$ The impact of surface roughness on plaque reten-tion that may lead to secondary caries, and gingival irritation, has been stated. ${ }^{15,16}$ Bollen et al ${ }^{17}$ stat-ed that a 0.2 ųm of surface roughness was the threshold for bacterial plaque retention, and a clinical study showed that a restoration surface should have a maximum 0.5 ųm in mean surface roughness if it is not to be detected by the patient. ${ }^{18}$ Several restorative materials have been used for the restoration of caries and noncaries cervical le-sions. In addition to traditional resin composites, flowable composites and/ or glass ionomer restora-tives are preferred for Class $\mathrm{V}$

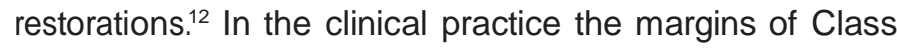
$V$ restorations are often located at adjacent or under the gingival margin. Using ultrasonic and air polishing devices for periodontal therapy could affect the surface texture of restorative material and thus could affect the periodontal 
health. ${ }^{19}$ The aim of this study was to investigate the effects of ultrasonic scaling, air polishing and mouth rinses on the surface roughness of different adhesive restorative materials. The null hypothesis of this in vitro study was that there were no statistically significant differences between different adhesive restorative materials after two different polishing protocols and mouth rinse applications.

\section{MATERIALS AND METHODS}

\section{Experimental design}

A reinforced conventional glass ionomer (Fuji IX GP Extra, GC Dental, Tokyo, Japan), a resin modified glass ionomer (Fuji II LC, GC Dental, Tokyo, Japan), a flowable composite (G-ænial Universal Flo, GC Dental, Tokyo, Japan), and a nanohybrid composite (GC Kalore, GC Dental, Tokyo, Japan) were used as testing materials. Forty specimens for each restorative material were fabricated and polished to produce an initial surface finish. After the baseline surface roughness measurements, the specimens were divided into two groups according to the prophylactic polishing protocols. And following polishing protocols the groups were divided into two subgroups and immersed in two different mouth rinses. Four tooth colored restorative materials, all of A2 shade, and mouth rinses used in this study are described in Table 1. The average surface roughness $(\mathrm{Ra})$ was recorded using a profilometer at four stages and the flow chart of the research is shown in Figure 1.

\begin{tabular}{|c|c|c|c|}
\hline Material & Type & Composition & $\begin{array}{l}\text { Manu- } \\
\text { facturer }\end{array}$ \\
\hline $\begin{array}{l}\text { Fuji IX GP } \\
\text { Extra }\end{array}$ & $\begin{array}{l}\text { Reinforced } \\
\text { Conventional } \\
\text { Glass lono- } \\
\text { mer }\end{array}$ & $\begin{array}{l}\text { Powder:Alumino fluoro } \\
\text { silicate glass; polyacrylic } \\
\text { acid Liquid: Distilled } \\
\text { water; polyacrylic acid; } \\
\text { polybasic carboxylic } \\
\text { acid }\end{array}$ & $\begin{array}{l}\text { GC, } \\
\text { Tokyo, } \\
\text { Japan }\end{array}$ \\
\hline Fuji II LC & $\begin{array}{l}\text { Resin Mod- } \\
\text { ified Glass } \\
\text { lonomer }\end{array}$ & $\begin{array}{l}\text { Powder: Fluoroaluminos- } \\
\text { ilicate glass } \\
\text { Liquid: acrylic acid, ma- } \\
\text { leic acid, HEMA, water, } \\
\text { comphor- quinone }\end{array}$ & $\begin{array}{l}\text { GC, } \\
\text { Tokyo, } \\
\text { Japan }\end{array}$ \\
\hline GC Kalore & $\begin{array}{l}\text { Nanohybrid } \\
\text { Composite }\end{array}$ & $\begin{array}{l}\text { UDMA, DX } 511 \text { comono- } \\
\text { mers, Al-Si glass filler, } \\
\text { prepolymerized filler } \\
\text { silicon dioxide }\end{array}$ & $\begin{array}{l}\text { GC, } \\
\text { Tokyo, } \\
\text { Japan }\end{array}$ \\
\hline $\begin{array}{l}\text { G-ænial } \\
\text { Universal } \\
\text { Flo }\end{array}$ & $\begin{array}{l}\text { Nanohybrid } \\
\text { Flowable } \\
\text { Composite }\end{array}$ & $\begin{array}{l}\text { UDMA, Bis-MEPP TEGD- } \\
\text { MA, Silicon dioxide }\end{array}$ & $\begin{array}{l}\text { GC, } \\
\text { Tokyo, } \\
\text { Japan }\end{array}$ \\
\hline
\end{tabular}

\begin{tabular}{|c|c|c|c|}
\hline $\begin{array}{l}\text { Oral-B Pro } \\
\text { Expert } \\
\text { Clinic Line } \\
\text { Alco- } \\
\text { hol-free }\end{array}$ & $\begin{array}{l}\text { Alcohol-free } \\
\text { mouth rinse }\end{array}$ & $\begin{array}{l}\text { Aqua, Glycerin, Polysorbate } \\
\text { 20, Aroma, Methylpara- } \\
\text { bene, Cetylpyr-idinium } \\
\text { Chloride, Sodium Floride, } \\
\text { Sodium Saccharin, Sodium } \\
\text { Benzo-ate, Propylparaben, } \\
\text { Cl42051, Cl } 47005\end{array}$ & $\begin{array}{l}\text { Oral-B, } \\
\text { Procter \& } \\
\text { Gamble, } \\
\text { Gross } \\
\text { Gerau, } \\
\text { Germany }\end{array}$ \\
\hline $\begin{array}{l}\text { Listerine } \\
\text { Coolmint }\end{array}$ & Mouth rinse & $\begin{array}{l}\text { Aqua, Alcohol, Sorbitol, } \\
\text { Polox-amer 407, Benzoic } \\
\text { Acid, Sodium Saccharin, } \\
\text { Eucalyptol, Aroma, Me-thyl } \\
\text { Salicylate, Thymol, Menthol, } \\
\text { Sodium Benzoat, CL } 42053\end{array}$ & $\begin{array}{l}\text { (John- } \\
\text { son \& } \\
\text { John-son } \\
\text { Limited, } \\
\text { Maiden- } \\
\text { head, UK) }\end{array}$ \\
\hline
\end{tabular}

Table 1. Characteristics of materials used in the study

\section{Specimen Preparation}

Forty disc-shaped specimens, in $8.0 \mathrm{~mm}$ in diameter and 2.0 $\mathrm{mm}$ in height, for each restorative material were prepared. Uncured restorative materials were placed into a stainless steel mould and a poly-ester matrix strip (Mylar Strip, SS White Co., Philadelphia, PA, USA) was placed on both sides. In order to remove the excess material and to have a flat surface, the mould was compressed between two glass. All samples, except Fuji IX GP Extra, were polymerized for 40 s with a halogen light unit (VIP, Bisco Inc., Schaumburg, IL, USA, $600 \mathrm{~mW} / \mathrm{cm}^{2}$ ). A radiometer (Hilux Curing Light Meter, Benlioglu Dental Inc., Ankara, Turkey) was used to check the light intensity of the curing light. For the self-cured glass ionomer cement, specimens were left untouched for 10 minutes. As the specimens were cured, they were removed from the moulds. The group and specimen numbers were marked to one side of the disks and they all kept in distilled water at $37^{\circ} \mathrm{C}$ for 24 hours. The unmarked surfaces were ground with 600 grit silicon carbide (SiC) paper for $20 \mathrm{~s}$, then were polished with $12.5 \mathrm{~mm}$ Sof-Lex Polishing Discs (3M ESPE, St.Paul, MN, USA) under dry conditions, from medium to superfine. Debris was removed by water rinsing between each disc usage.

\section{Roughness measurement}

The surface roughness average $\left(R_{a}, u m\right)$ was assessed by a two-dimensional profilometer (Surtronic $3^{+}$, Taylor Hobson, Leicester, UK). Five measurements were performed and the mean value of these five readings were used for analysis. The roughness measurements were obtained at four stages: before scaling (baseline), after prophylac- 
tic polishing protocols, after mouth rinses immersion and after re-polishing

\section{Prophylactic polishing protocols}

All prophylactic polishing protocols were performed by one experienced periodontist.

\section{Ultrasonic scaling}

The surface of the specimens were subjected to ultrasonic scaling (Cavitron Jet Plus, Dentsply, Kon-stanz, Germany) for 8 seconds. The directions of the ultrasonic scaling were approximately $15^{\circ}$ to the restorative surface in order to mimic the clinical situation as much as possible. Following this, the surface of the specimens were subjected to pumice-water slurry (Detartrine, Septodont, Saint-Maur-des-Fosses, France) with a rotating rubber cup for 3 seconds in a contra-angle low speed handpiece at $2000 \mathrm{rpm}$.

\section{Ultrasonic scaling + Air Polishing}

After ultrasonic scaling the surfaces of the specimens were treated with an air polishing device (Air Flow Handy, EMS, Nyon, Switzerland) for 5 seconds with an air pressure of 4,55 bar. Sodium bi-carbonate powder (EMS AirFlow Powder, EMS) was the abrasive of the air polishing device and its nozzle was perpendicular to the surface with a $2 \mathrm{~mm}$ distance. Following this application the surface of the specimens were subjected to pumice-water slurry as explained above.

\section{Mouth rinse immersion protocol}

The specimens were immersed in $20 \mathrm{ml}$ of mouth rinse for 12 hours, which was equivalent in time to 1 year of $2 \mathrm{~min}$ daily use. ${ }^{19}$ Specimens were kept at $37^{\circ} \mathrm{C}$ throughout the study, and mouth rinses were shaken every hour to provide homogeneity. After 12 hours, the specimens were removed, immersed in deionized water.

\section{Re-polishing}

The surfaces were re-polished with polishing discs as explained briefly in the specimen preparation section above.

\section{Statistical Analysis}

The differences of surface roughness values were calculated (prophylactic polishing-baseline, mouth rinse immersion-prophylactic polishing, re-polishing- mouth rinse immersion). Shapiro-Wilk test was used to test the normal distribution of data. To test changes among the differences of the measure-ments repeated measures ANOVA was used with fixed factors as materials, polishing group and mouth rinse group. To test differences among the baseline measurements four-way ANOVA and Bonferroni multiple comparison method was used. All statistical analysis was carried out at signifi-cance level 0.05. SPSS 21.0 for Windows (SPSS Inc. Chicago, IL, USA) was used for the statistical analysis.

\section{RESULTS}

All (baseline, prophylactic polishing, mouth rinse, re-polishing) surface roughness values and standard deviations of each restorative material groups $(n=40)$ were presented in Table 2.

\begin{tabular}{|c|c|c|c|c|c|c|}
\hline Materials & & Groups & & Roughne & Measurements & \\
\hline \multirow{5}{*}{$\begin{array}{l}\text { Fuji IX GP } \\
\text { Extra }\end{array}$} & (PPP) & Mouthrinses & Baseline & PPP & MIP & RPP \\
\hline & \multirow{2}{*}{ US } & LISTERINE & $0,45 \pm 0,13$ & $0,66 \pm 0,10$ & $0,65 \pm 0,13$ & $0,47 \pm 0,07$ \\
\hline & & Oral-B & $0,47 \pm 0,11$ & $0,67 \pm 0,16$ & $0,70 \pm 0,16$ & $0,57 \pm 0,13$ \\
\hline & \multirow{2}{*}{ US+AP } & LISTERINE & $0,45 \pm 0,11$ & $1,27 \pm 0,26$ & $1,36 \pm 0,51$ & $0,61 \pm 0,14$ \\
\hline & & Oral-B & $0,47 \pm 0,07$ & $1,27 \pm 0,25$ & $1,31 \pm 0,30$ & $0,58 \pm 0,15$ \\
\hline \multirow{4}{*}{ Fuji II LC } & \multirow{2}{*}{ US } & LISTERINE & $0,56 \pm 0,08$ & $0,89 \pm 0,16$ & $0,87 \pm 0,12$ & $0,53 \pm 0,11$ \\
\hline & & Oral-B & $0,52 \pm 0,14$ & $0,80 \pm 0,14$ & $0,77 \pm 0,10$ & $0,57 \pm 0,09$ \\
\hline & \multirow{2}{*}{ US+AP } & LISTERINE & $0,53 \pm 0,08$ & $1,72 \pm 0,17$ & $1,72 \pm 0,19$ & $0,56 \pm 0,10$ \\
\hline & & Oral-B & $0,54 \pm 0,14$ & $1,65 \pm 0,16$ & $1,67 \pm 0,24$ & $0,55 \pm 0,11$ \\
\hline \multirow{4}{*}{$\begin{array}{l}\text { G-ænial } \\
\text { Universal Flo }\end{array}$} & \multirow{2}{*}{ US } & LISTERINE & $0,20 \pm 0,04$ & $0,20 \pm 0,03$ & $0,18 \pm 0,03$ & $0,15 \pm 0,02$ \\
\hline & & Oral-B & $0,23 \pm 0,04$ & $0,24 \pm 0,03$ & $0,21 \pm 0,04$ & $0,16 \pm 0,02$ \\
\hline & \multirow{2}{*}{ US + AP } & LISTERINE & $0,18 \pm 0,04$ & $0,42 \pm 0,09$ & $0,42 \pm 0,09$ & $0,14 \pm 0,02$ \\
\hline & & Oral-B & $0,19 \pm 0,03$ & $0,40 \pm 0,06$ & $0,41 \pm 0,07$ & $0,16 \pm 0,04$ \\
\hline \multirow{4}{*}{ GC Kalore } & \multirow{2}{*}{ US } & LISTERINE & $0,15 \pm 0,01$ & $0,18 \pm 0,07$ & $0,20 \pm 0,11$ & $0,11 \pm 0,01$ \\
\hline & & Oral-B & $0,16 \pm 0,03$ & $0,18 \pm 0,04$ & $0,17 \pm 0,05$ & $0,12 \pm 0,02$ \\
\hline & \multirow{2}{*}{ US+AP } & LISTERINE & $0,17 \pm 0,03$ & $0,22 \pm 0,05$ & $0,22 \pm 0,05$ & $0,14 \pm 0,02$ \\
\hline & & Oral-B & $0,16 \pm 0,03$ & $0,18 \pm 0,06$ & $0,18 \pm 0,06$ & $0,12 \pm 0,02$ \\
\hline
\end{tabular}

Table 2. All surface roughness values and standard deviations of each restorative material groups

When baseline measurements were compared, the mean surface roughness values of GC Kalore and G-ænial Universal Flo were observed to be similar $(p=0.196)$ while they were significantly lover from the other materials $(p<0.05)$. After prophylactic polishing procedures it was seen that using air polishing device after ultrasonic scaling resulted in significant increases in surface roughness $(p<0.001)$. Statistical 
analysis of the results showed that after prophylactic polishing procedures, resin composites GC Kalore and G-ænial Universal Flo represented similar roughness differences $(p=0.061)$ and the roughness differences of glass ionomers (Fuji IX GP Extra and Fuji II LC) were higher than these two composites. The differences of the roughness values of Fuji II LC was evaluated as the highest ( $p<0.001)$ (Table 3).

\begin{tabular}{|c|c|c|c|c|c|c|}
\hline \multirow{2}{*}{ Materials } & \multirow{2}{*}{ PPP } & \multirow{2}{*}{ Mouthrinses } & \multicolumn{2}{|c|}{$\triangle$ PPP-Baseline } & \multicolumn{2}{|c|}{$\triangle \mathrm{MIP}$ - PPP } \\
\hline & & & Mean & $\begin{array}{c}\text { Std. } \\
\text { Deviation }\end{array}$ & Mean & $\begin{array}{c}\text { Std. } \\
\text { Deviatior }\end{array}$ \\
\hline \multirow{4}{*}{$\begin{array}{l}\text { Fuji IX GP Ex- } \\
\text { tra }\end{array}$} & \multirow{2}{*}{ US } & LISTERINE & $0,21^{\mathrm{a}}$ & 0,12 & $-0,01^{b}$ & 0,11 \\
\hline & & Oral-B & $0,20^{a}$ & 0,21 & $0,02^{2, b}$ & 0,20 \\
\hline & \multirow{2}{*}{$\mathrm{US}+\mathrm{AP}$} & LISTERINE & $0,82^{a}$ & 0,27 & $0,09^{b}$ & 0,42 \\
\hline & & Oral-B & $0,80^{a}$ & 0,26 & $0,05^{b}$ & 0,37 \\
\hline \multirow{4}{*}{ Fuji II LC } & \multirow{2}{*}{ US } & LISTERINE & $0,33^{a}$ & 0,09 & $-0,02^{\mathrm{b}}$ & 0,07 \\
\hline & & Oral-B & $0,28^{a}$ & 0,22 & $-0,03^{b}$ & 0,16 \\
\hline & \multirow{2}{*}{$\mathrm{US}+\mathrm{AP}$} & LISTERINE & $1,19^{a}$ & 0,18 & $0,00^{b}$ & 0,24 \\
\hline & & Oral-B & $1,11^{a}$ & 0,16 & $0,02^{b}$ & 0,18 \\
\hline \multirow{4}{*}{$\begin{array}{l}\text { G-ænial Uni- } \\
\text { versal Flo }\end{array}$} & \multirow{2}{*}{ US } & LISTERINE & $0,01^{\mathrm{a}}$ & 0,05 & $-0,02^{a}$ & 0,04 \\
\hline & & Oral-B & $0,01^{\circ}$ & 0,06 & $-0,03^{a}$ & 0,06 \\
\hline & \multirow{2}{*}{ US+AP } & LISTERINE & $0,24^{\circ}$ & 0,08 & $0,00^{b}$ & 0,06 \\
\hline & & Oral-B & $0,21^{a}$ & 0,07 & $0,00^{b}$ & 0,05 \\
\hline \multirow{4}{*}{ GC Kalore } & \multirow{2}{*}{ US } & LISTERINE & $0,03^{a}$ & 0,06 & $0,02^{a}$ & 0,12 \\
\hline & & Oral-B & $0,02^{a}$ & 0,04 & $-0,01^{\mathrm{a}}$ & 0,05 \\
\hline & \multirow{2}{*}{$\mathrm{US}+\mathrm{AP}$} & LISTERINE & $0,04^{a}$ & 0,05 & $0,01^{a}$ & 0,04 \\
\hline & & Oral-B & $0,02^{a}$ & 0,07 & $0,00^{\circ}$ & 0,02 \\
\hline
\end{tabular}

Table 3. Mean and standard deviation of the differences of surface roughness values of the groups. "Prophylactic Polishing Protocols: PPP, Mouth rinses Immersion Protocol: MIP, Re-polishing Protocol: RPP"

Considering the effect of two mouth rinses with different ingredients on the surface roughness of tested restorative materials, it was found that mouth rinses had similar effects on the surface roughness of the materials $(p=0.877)$. When we evaluated the impact of two different mouth rinses within the test materials, there was no statistically significant difference observed between the mean surface roughness values after mouth rinse immersion procedures ( $p>0.05)$. And also the two prophylactic polishing protocols did not significantly affect the differences of surface roughness that was measured after mouth rinse immersion protocol $(p=0.57)$. When we assessed the re-polishing procedures, it was observed that, re-polishing decreased the roughness of all tested materials. The differences were not significant $(p=0.29)$ for the resin composites but significant for glass ionomers $(p<0.001)$ (Table 3$)$. Regarding the variable interactions it was observed in (Table 4) that since the "Differences *Materials* Prophylactic Polishing Protocols" interaction term was statistically significant, the dissimilarities between differences due to materials and also Prophylactic Polishing Protocols were different ( $p<0,001)$. "Differences" represents the test of the differences between these three repeated delta measurements (^ PPP-Baseline, ^ MIP _ PPP,^RPP-MIP).

\begin{tabular}{|l|l|l|}
\hline Source & F & Sig. \\
\hline Differences & 463,236 & $<0,001$ \\
\hline Differences*Materials & 93,745 & $<0,001$ \\
\hline $\begin{array}{l}\text { Differences* Prophylactic } \\
\text { Polishing Protocols }\end{array}$ & 173,059 & $<0,001$ \\
\hline Differences*Mouth rinses & 1,158 & 0,312 \\
\hline $\begin{array}{l}\text { Differences*Materials* Pro- } \\
\text { phylactic Polishing Protocols }\end{array}$ & 35,402 & $<0,001$ \\
\hline $\begin{array}{l}\text { Differences*Materials* Mouth } \\
\text { rinses }\end{array}$ & 0,196 & 0,971 \\
\hline $\begin{array}{l}\text { Differences * Prophylactic } \\
\text { Polishing Protocols * Mouth } \\
\text { rinses }\end{array}$ & 0,062 & 0,925 \\
\hline $\begin{array}{l}\text { Differences*Materials* Pro- } \\
\text { phylactic Polishing Protocols * } \\
\text { Mouth rinses }\end{array}$ & 0,147 & 0,985 \\
\hline
\end{tabular}

\section{Table 4. ANOVA table}

\section{DISCUSSION}

In the dental market there are a many different restorative materials for esthetic restorations. The surface roughness of restorative materials is an important factor for maintaining esthetic results and clinical success of the restorations. Surface irregularities of the restorations may cause plaque and stain retention. This accumulation may lead to gingival inflammation and solubility of the organic matrix due to the acids formed in plaque. ${ }^{20}$ Also the surface irregularities of these restorations can initiate biofilm formation.13

The removal of plaque and calcified deposits from tooth surfaces, which is accomplished by sonic and ultrasonic scaling systems, is an essential part of periodontal therapy. ${ }^{12}$ This procedure may affect not only dental tissues but 
also the surface of restorative materials. Currently reported studies primarily investigate the finishing and polishing of restorative materials or the effects of new air-polishing techniques on restorative materials. ${ }^{21}$ Although the side effects of periodontal instrumentation on tooth surfaces have been well investigated, few studies have looked at their effects on restorative materials. ${ }^{10}$ It could be supposed that scaling procedures may damage the marginal integrity of cervical restorations, thus leading to the development of tooth sensitivity and adversely affecting the longevity and esthetic appearance of the restorations. ${ }^{22}$

In our in vitro study it was seen that, ultrasonic scaling with or without air polishing device resulted in significant increases in surface roughness. However the effect of air polishing device was higher. Similar to our findings, Yap et al. ${ }^{23}$ concluded that the roughest surface was observed after air-powder polishing. Carr et al. ${ }^{24}$ suggested that surface roughness was increased after exposure to air polishing instrumentation. They emphasized that clinicians should be more careful when they are using air polishing devices close to esthetic restorations.

Smooth resin composite surfaces exhibit less bacterial accumulation, ${ }^{25}$ and so material surface alteration is another factor in determining bacterial adhesion. ${ }^{26}$ There have been several different resin composites introduced to dental market with different physical properties like filler quantity, particle ingredient, shape and volume. These materials containing fillers, tend to absorb energy in order to lessen the formation of surface micro cracks in the materials..$^{13}$ Composite structure and the characteristics of the inorganic fillers have a direct impact on composite resin surface smoothness. ${ }^{27}$ In the present study, it was observed that nano hybrid resin composite GC Kalore and flowable composite G-ænial Universal Flo represented smoother surfaces than the other two glass ionomers at the beginning of the study, and prophylactic polishing procedures resulted in statistically significant changes in surface roughness. Thus, the null hypothesis that different prophylactic polishing protocols did not interfere with surface roughness of adhesive restorative materials was rejected. It was ob-served that both prophylactic polishing procedures significantly roughened the surfaces of all tested groups; however, air polishing device more adversely affected the surface roughness than ultrasonic scaling, especially in Fuji IX GP Extra and Fuji II LC groups. Similar to our findings Erdilek et al. ${ }^{22}$ showed that glass ionomer restorative that they tested exhibited the roughest surfaces, while the flowable resin composite had the smoothest surfaces. In addition to this literature, Lin et al. ${ }^{12}$ revealed that glass ionomers were more prone to surface alterations than resin composites. The surface roughness of restorative materials is important for staining, patient comfort and especially plaque re-tention. In a study it was reported that patients were able to detect the roughness within the range of $0.25-0.50$ ųm;18 it is also reported that the threshold surface roughness for bacterial retention is 0.2 ųm. ${ }^{17,22}$ The initial roughness of tested materials were 0.46 , 0.54, 0.20 and 0.16 ųm respectively for Fuji IX GP Extra, Fuji II LC, G-ænial Universal Flo and GC Kalore. The high roughness value of glass ionomer restoratives could be related to the heterogeneous and biphasic nature of these materials. ${ }^{12}$ Prophylactic polishing procedures increased the surface roughness however, mouth rinse effect on the roughness differences was not statistically significant. The results of the present study also indicate that repolishing decreases the roughness values to near baseline levels (Table 2). According to these findings it could be revealed that repolishing may be important for smoothing the restoratives after prophylactic polishing protocols. Similar to our observations, Yap et al. ${ }^{23}$ mentioned that resin composites generally require repolishing after exposure to some hygiene maintenance procedures.

In clinical conditions, the mouth rinse effects on restorative materials may depend on many clinical factors that cannot be simulated in vitro. Saliva, pellicle, foods and beverages may decrease or in-crease the effects of mouthrinses. ${ }^{28}$ Gürgan et al. ${ }^{29}$ reported that independently from the alcohol ingredient, mouth rinses affected the hardness of resin composites. Similarly, it was stated in a differ-ent literature that 
mouth rinses could affect composite hardness directly related with the percentage of alcohol. ${ }^{30}$ However, Gürdal et al. ${ }^{28}$ concluded that alcohol content had no significant effect on the microhardness of adhesive restorative materials. In our study, both mouth rinses with and without alcohol did not have a statistically significant effect on surface roughness differences. In this sense, this finding of ours was similar to that reported by Gürdal et al. ${ }^{28}$ Glass ionomer restoratives are gen-erally indicated for root restorations, because of their ability to release fluoride and therefore act in an anticariogenic manner. ${ }^{13}$ With regard to the performance of different materials, it can be concluded in our study that glass ionomers revealed the greatest increases in mean roughness of all test materials, while resin composites showed the smallest increase. After re-polishing the roughness values were decreased near baseline levels but these values were higher than the threshold surface roughness for bacterial retention which is 0.2 ųm for glass ionomers.

\section{CONCLUSIONS}

In the light of the results obtained in this in vitro study, it could be concluded that; prophylactic pro-cedures especially air polishing protocol increased the roughness of adhesive restorative materials. With respect to critical threshold surface roughness for bacterial adhesion resin composites would be a better choice for Class V restorations. Based on these knowledge routine periodontal prophylactic protocols should be carried with caution; and re-polishing of roughened restorations after these scal-ing procedures might be indicated.

\section{REFERENCES}

1. Worthington HV, Clarkson JE, Bryan G, Beirne PV. Routine scale and polish for periodontal health in adults. Cochrane Database Syst Rev 2013; 11: 1-68

2. Petersilka GJ, Bell M, Häberlein I, et al. In vitro evaluation of novel low abrasive air polishing powders. J Clin Periodontol 2003; 30: 9-13

3. Kimyai S, Savadi-Oskoee S, Ajami AA, et al. Effect of three prophylaxis methods on surface roughness of giomer. Med Oral Patol Oral Cir Bucal 2011; 16: 114.

4. Graumann SJ, Sensat ML, Stoltenberg JL. Air polishing: A review of current litrature. J Dent Hyg 2013; 87: 173-180.

5. Pihlstrom BL1, Michalowicz BS, Johnson NW. Periodontal diseases. Lancet 2005; 366: 1809-1820.

6. Mandel ID. Antimicrobial mouthrinses: overview and update. J Am Dent Assoc 1994; 125: 2-10.

7. Commission FDI. Mouthrinses and periodontal disease. Int Dent J 2002; 52: 346-352.

8. Mankodi S, Bauroth K, Witt JJ, et al.A 6-month clinical trial to study the effects of a cetylpyridini-um chloride mouthrinse on gingivitis and plaque. Am J Dent 2005; 18: 9-14.

9. Witt JJ, Walters P, Bsoul S, et al.Comparative clinical trial of two antigingivitis mouthrinses. Am J Dent 2005; 18: 15-17. 10. Folwaczny M, Merkel U, Mehl A, Hickel R. Influence of parameters on root surface roughness following treatment with a magnetostrictive ultrasonic scaler: an in vitro study. J Periodontol 2004; 75: 1221-1226.

11. Kishida M, Sato S, Ito K.Effects of a new ultrasonic scaler on fibroblast attachment to root surfac-es: a scanning electron microscopy analysis. J Periodontal Res 2004; 39: 111-119.

12. Lai YL, Lin YC, Chang CS, Lee SY.Effects of sonic and ultrasonic scaling on the surface roughness of tooth-colored restorative materials for cervical lesions. Oper Dent 2007; 32: $273-278$

13. Mourouzis P1, Koulaouzidou EA, Vassiliadis L, Helvatjoglu-Antoniades M. Effects of sonic scaling on the surface roughness of restorative materials. J Oral Sci 2009; 51:607-614. 14. Colucci V, Dos Santos CD, Do Amaral FL, et al. Influence of $\mathrm{NaHCO} 3$ powder on translucency of microfilled composite resin immersed in different mouthrinses. J Esthet Restor Dent 2009; 21: 242-248.

15. Jefferies SR. Abrasive finishing and polishing in restorative dentistry: a state-of-the-art review. Dent Clin North Am 2007; 51: 379-397.

16. Furuse AY, Gordon K, Rodrigues FP, et al. Colour-stability and gloss-retention of silorane and dimethacrylate composites with accelerated aging. J Dent 2008; 36: 945-952. 
17. Bollen CM, Lambrechts P, Quirynen M.Comparison of surface roughness of oral hard materials to the threshold surface roughness for bacterial plaque retention: a review of the literature. Dent Ma-ter 1997; 13: 258-269.

18. Jones CS, Billington RW, Pearson GJ. The in vivo perception of roughness of restorations. Br Dent J 2004; 196: 42-45.

19. Gurgan, S, Yalcin Cakir F. The effect of three different mouthrinses on the surface hardness, gloss and colour change of bleached nano composite resins. Eur J Prosthodont Restor Dent 2008; 16: 104-108.

20. Roeder LB, Tate WH, Powers JM. Effect of finishing and polishing procedures on the surface roughness of packable composites. Oper Dent 2000; 25: 534-543.

21. Warren DP, Colescott TD, Henson HA, Powers JM. Effects of four prophylaxis pastes on surface roughness of a composite, a hybrid ionomer, and a compomer restorative material. J Esthet Restor Dent 2002; 14: 245-251.

22. Erdilek D, Sismanoglu S, Gumustas B, Efes BG. Effects of ultrasonic and sonic scaling on surfaces of tooth-colored restorative materials: An in vitro study. Niger J Clin Pract 2015; 18: 467-471.

23. Yap AU, Wu SS, Chelvan S, Tan ES.Effect of hygiene maintenance procedures on surface rough-ness of composite restoratives. Oper Dent 2005; 30: 99-104.

24. Carr MP, Mitchell JC, Seghi RR, Vermilyea SG. The effect of air polishing on contemporary es-thetic restorative materials. Gen Dent 2002; 50: 238-241.

25. Ikeda I, Otsuki M, Sadr A, et al. Effect of filler content of flowable composites on resin-cavity inter-face. Dent Mater J 2009; 28: 679-685.

26. Poggio C, Arciola CR, Rosti F, et al. Adhesion of Streptococcus mutans to different restorative materials. Int $\mathrm{J}$ Artif Organs 2009; 32: 671-677.

27. Festuccia MS1, Garcia Lda F, Cruvinel DR, Pires-De-Souza Fde C. Color stability, surface roughness and microhardness of composites submitted to mouthrinsing action. J Appl Oral Sci 2012; 20: 200-205.

28. Gürdal P, Akdeniz BG, Hakan Sen B. The effects of mouthrinses on microhardness and colour stability of aesthetic restorative materials. J Oral Rehabil 2002; 29: 895901.

29. Gürgan S, Onen A, Köprülü H. In vitro effects of alcohol-containing and alcohol-free mouthrinses on microhardness of some restorative materials. J Oral Rehabil 1997; 24: 244-246.

30. Penugonda B, Settembrini L, Scherer W, Hittelman E, Strassler $\mathrm{H}$. Alcohol-containing mouth-washes: effect on composite hardness. J Clin Dent 1994; 5: 60-62.

\section{7tepeklinik}

